\title{
Discovery of granulitized eclogite in North Sikkim expands the Eastern Himalaya high-pressure province
}

\author{
Franco Rolfo ${ }^{1 *}$, Rodolfo Carosi ${ }^{2}$, Chiara Montomoli ${ }^{2}$ and Dario Visonà ${ }^{3}$ \\ 1 Dipartimento di Scienze Mineralogiche e Petrologiche, University of Torino, ITALY \\ 2 Dipartimento di Scienze della Terra, University of Pisa, ITALY \\ 3 Dipartimento di Geoscienze, University of Padova, ITALY \\ * For correspondence, email:franco.rolfo@unito.it
}

Eclogite occurrences are very few in the Himalayas and mainly consist of two types (Lombardo and Rolfo 2000): the coesitebearing eclogites of the western Himalaya (Kaghan valley: O'Brien et al. 2001; Tso Morari: Sachan et al. 2004) and the granulitized eclogites of the eastern Himalaya (Ama Drime range: Lombardo et al. 1998).

Unlike the "western type" eclogites, where post-peak decompression under constant to decreasing temperature suggests exhumation favoured by thrusting associated with accretion of the metamorphic pile onto the base of the over-riding plate, the "eastern type" Ama Drime eclogites were probably exhumed relatively slowly and were subjected to thermal relaxation in the thickened continental crust producing a strong granulite-facies overprint at intermediate crustal levels.

A new finding of granulitized eclogites in North Sikkim, east of Mount Kangchendzonga and some $120 \mathrm{~km}$ southeast of the Ama Drime, extends the eclogite province in eastern Himalaya.

Mount Kangchendzonga sits at the western flank of the Ranjit Tectonic Window (RTW), a regional structure cutting deeply through the Himalayan nappe pile. At low structural levels, the RTW exposes low grade Lesser Himalayan schists overlying unmetamorphosed Permo-Carboniferous sedimentary rocks of Gondwanian affinity. At higher structural levels, the northern end of the RTW shows an increase in metamorphic grade through the Main Central Thrust zone up to migmatites with garnet-bearing leucosomes in the Higher Himalayan Crystallines (HHC). In north Sikkim, along the Zemu Glacier east of Kangchendzonga, HHC main lithologies are granite to granodiorite orthogneiss with intercalations of biotite-rich paragneiss and very rare metabasites. Rolfo et al. (2006) gave a preliminary description of this geologic transect, where the main fabric is folded by two systems of later folds trending NNE-SSW and WNW-ESE with steeply dipping axial planes. The RTW can be the result of the interference pattern between these two later system of folds. Compressive and extensional shear zones with a top both to the SW and SE sense of shear respectively affect the main foliation. Top to the SE shear zones can be correlated with normal shear zones recognized in the nearmost western Bhutan (Carosi et al. 2006), developed during the extrusion of the HHC.

The lithological associations of the HHC in the Zemu Glacier area are comparable to those described south of Mt. Kangchendzonga by Vezzoli et al. (2005). Among metabasites collected in the drainage of Zemu Glacier, a few samples are very similar to the granulitized eclogites first described in eastern
Himalaya by Lombardo et al. (1998) in the Ama Drime range, southern Tibet.

Microstructure of the North Sikkim granulitized eclogite is medium grained, granoblastic and little deformed. It is characterised by the occurrence of well preserved porphyroblastic garnet crystals several mm across, surrounded by a thick plagioclase + orthopyroxene corona, and a matrix mainly made of brown amphibole and plagioclase together with minor quartz, biotite and opaque minerals. Primary omphacite is not preserved, but is replaced by a distinctive symplectite of plagioclase + amphibole. Compared to the Ama Drime eclogite, the typical plagioclasebiotite intergrowths replacing pristine phengite occur very rarely and ilmenite aggregates and minor magnetite are locally abundant.

Though strongly re-equilibrated to granulite and amphibolite facies, the North Sikkim eclogite is clearly comparable to the Ama Drime eclogite. Bulk rock composition is analogous, showing a moderately high $\mathrm{SiO}_{2}$ content (from 52 to $53 \mathrm{wt} \%)$, medium $\mathrm{K}_{2} \mathrm{O}(0.54 \mathrm{wt} \%)$ and low $\mathrm{MgO}(5.47$ $\mathrm{wt} \%)$ contents. Ti content is relatively high $\left(\mathrm{TiO}_{2}=2.77 \mathrm{wt} \%\right)$ as well as the Fe content (FeOtot $=14.79 \mathrm{wt} \%$ ), suggesting Fe-rich basalt as protolith. Most minerals of the high-pressure peak assemblage are not preserved, safe for the eclogitic cores of garnet (Grs18-20, Alm55-56, Prp08-09, Sps08-09) very similar in composition to those of Ama Drime eclogite (Groppo et al. 2007). As a whole, chemical compositions of the North Sikkim eclogite main assemblage (garnet, pyroxene, amphibole) are strongly similar to those of Ama Drime eclogite, suggesting a comparable metamorphic evolution.

Mineralassemblages, reaction textures, geothermobarometry and isochemical phase diagram P-T sections suggest that at least three superposed metamorphic events have been recorded in the North Sikkim eclogite. The first event was eclogitic, with $\mathrm{T}>$ $600^{\circ} \mathrm{C}$ and $\mathrm{P}>1.5 \mathrm{GPa}$, but is poorly constrained because of the nearly complete lack of eclogitic mineral relics. The second event was granulitic and is represented by the plagioclase + orthopyroxene corona around garnet, with medium $\mathrm{P}(>0.4$ $\mathrm{GPa}$ ) and high $\mathrm{T}\left(\mathrm{ca} .750^{\circ} \mathrm{C}\right)$. The third event at comparable $\mathrm{P}$ and lower $\mathrm{T}\left(<720^{\circ} \mathrm{C}\right)$ is marked by the growth of brown amphibole and plagioclase in the matrix.

The discovery of strongly overprinted eclogite in North Sikkim extends significantly the high-pressure province of the eastern Himalaya and confirms the duality in tectonic style of exhumation along the Himalayan chain. 


\section{References}

Carosi R, C Montomoli, D Rubatto and D Visonà. 2006. Normal-sense shear zones in the core of the Higher Himalayan Crystalline (Bhutan Himalayas): evidence for extrusion? Geological Society of London, Special Pubblication 268: 425-444

Groppo C, B Lombardo, F Rolfo and P Pertusati. 2007. Clockwise exhumation path of granulitized eclogites from the Ama Drime Range (Eastern Himalayas). Journal of Metamorphic Geology 25: 51-75

Lombardo B, P Pertusati, F Rolfo and D Visonà. 1998. First report of eclogites from the E Himalaya: implications for the Himalayan orogeny. Memorie di Scienze Geologiche 50: 67-68

Lombardo B and F Rolfo. 2000. Two contrasting eclogite types in the Himalayas: implications for the Himalayan orogeny. Journal of Geodynamics 30: 37-60
O'Brien PJ, N Zotov, R Law, M Ahmed Khan and M Qasim Jan. 2001. Coesite in Himalayan eclogite and implications for models of IndiaAsia collision. Geology 29: 435-438

Rolfo F, R Carosi, C Montomoli, D Visonà and IM Villa. 2006. A geological transect east of Kangchendzonga (north Sikkim, India). Journal of Asian Earth Sciences 26: 158

Sachan HK, MK Mukherjee, Y Ogasawara, S Maruyama, H Ishida, A Muko and N Yoshioka. 2004. Discovery of coesite from Indus Suture Zone (ISZ), Ladakh, India: Evidence for deep subduction. European Journal of Mineralogy 16: 235-240

Vezzoli G., B Lombardo and F Rolfo. 2005. A geological reconnaissance to southern Kangchendzonga massif. Géologie Alpine 44: 192 